Monika Gromek*

Lublin

\title{
Rodzina w teorii i praktyce pedagogicznej. W 20. rocznicę utworzenia Katedry Pedagogiki Rodziny w Instytucie Pedagogiki KUL, Lublin, 14 marca 2017 roku
}

W dniu 14 marca 2017 roku w Instytucie Pedagogiki Katolickiego Uniwersytetu Lubelskiego Jana Pawła II odbyła się Ogólnopolska Konferencja Naukowa „Rodzina w teorii i praktyce pedagogicznej. W 20. rocznicę utworzenia Katedry Pedagogiki Rodziny w Instytucie Pedagogiki KUL". Jej organizatorami były: Fundacja Centrum Opieki nad Rodziną „COR” oraz Katedra Pedagogiki Rodziny Instytutu Pedagogiki KUL. Otwarcia konferencji dokonała Pani Prodziekan ds. Studenckich i Kształcenia, dr hab. Ewa Domagała-Zyśk, oraz Dyrektor Instytutu Pedagogiki KUL, ks. prof. zw. dr hab. Marian Nowak.

Pierwsza część konferencji zatytułowana „Pedagogika rodziny wobec współczesnych wyzwań” była moderowana przez ks. prof. zw. dr. hab. Mariana Nowaka. Wystąpienie inaugurujące konferencję wygłosiła dr hab. Teresa Olearczyk, prof. KA, przedstawiając temat „Wychowanie w rodzinie jako przedmiot pedagogicznej refleksji - wychowanie przez pryzmat «wi-

* Mgr Monika Gromek jest doktorantką w Instytucie Pedagogiki Katolickiego Uniwersytetu Lubelskiego Jana Pawła II, w Katedrze Pedagogiki Rodziny. Adres: Instytut Pedagogiki KUL, ul. Droga Męczenników Majdanka 70,20-325 Lublin; e-mail: gromek.monika1@gmail. com. 
zerunku» rodziny". Prelegentka zwróciła uwagę na zmiany w rozumieniu celów i zadań rodziny, jakie niesie z sobą współczesność, oraz wskazała na konieczność specjalnego przygotowania młodych do podejmowania ról małżeńsko-rodzinnych. Pomimo specyfiki przemian i związanych z nimi trudności świata społecznego podstawowe wyznaczniki postaw rodzicielskich pozostają niezmienne: rozumna miłość obydwojga małżonków, wymagania dostosowane do wieku dzieci, odpowiedzialność rodziców za podejmowane decyzje oraz świadomość potrzeb i praw rozwojowych dziecka.

Następnie głos zabrał dr hab. Bogusław Bieszczad (UJ), przedstawiając referat: „O języku współczesnej pedagogiki rodziny”. Prelegent wskazał na zwiększającą się liczbę badań narracyjnych i empirycznych w obszarze pedagogiki rodziny oraz na istniejące różnice w stosowanej w nich terminologii, a także na wciąż trwającą dyskusję o statusie naukowym subdyscypliny. Zwrócił także uwagę na charakterystyczne dla współczesnej humanistyki tendencje do ujawniania się nowych subdyscyplin na pograniczu różnych nauk oraz odejście od linearnego i paradygmatycznego rozwoju, co w kontekście pedagogicznym określa się mianem transdyscyplinaryzacji przedmiotu pedagogiki, w tym także pedagogiki rodziny.

W dalszej kolejności referat pod tytułem „Deficyt wzorca osobowego mężczyzny a zaburzenia roli ojca" wygłosił dr hab. Jacek Kurzępa, prof. USWPS. Prelegent scharakteryzował pokrótce cechy współczesnego świata, wpływające na wypełnianie przez mężczyzn ról związanych z płcią. Następnie przywołał badania jakościowe i ilościowe dotyczące problemu obrazu ojca i podjął refleksję nad kwestiami: znaczenia autorytetu ojca, typowo męskich zachowań i tych wzorów postępowania, dla których odniesieniem jest ojciec.

Głosem zamykającym tę część obrad plenarnych było wystąpienie dr hab. Joanny Ostrouch-Kamińskiej, prof. UWM zatytułowane: „Demokratyzacja relacji małżeńskich i rodzicielskich we współczesnych rodzinach”. Prelegentka sformułowała trzy pytania odnoszące się do podejmowanego tematu: czym jest demokratyzacja relacji małżeńskich, czy jest to możliwe oraz w jaki sposób wprowadzić tę ideę w życie. Wskazała na istnienie analogii pomiędzy demokratyzacją małżeństwa a demokratyzacją społeczeństwa. Nawiązała do badań jakościowych dotyczących małżeństwa, gdzie wskazano na pewnego rodzaju model relacji małżeńskich, zawierający się w trzech elementach: wzajemna zależność, istnienie zasad regulujących relację małżeńską oraz podział odpowiedzialności i zaangażowania.

Drugą część obrad plenarnych moderowała dr hab. Joanna Ostrouch-Kamińska, prof. UWM. Kontynuowano w niej tematykę wyzwań współcze- 
sności, z którymi mierzy się pedagogika rodziny. Jako pierwsza głos zabrała prof. zw. dr hab. Jadwiga Izdebska z UWB. Przedstawiła temat: „Nowe oblicza wspólnoty rodzinnej w kontekście zachodzących zmian społeczno-kulturowych". Na wstępie wskazała, że podstawą każdej wspólnoty jest osobowy aspekt więzi i dobro wspólne. Rodzina jako podstawowa wspólnota ma swoją specyfikę, natomiast jej główna cecha to jakość więzi między jej członkami. W rodzinie zachodzi także proces zadomowienia, zakorzenienia w wartościach, kulturze, tradycji. Prelegentka wskazała na liczne społeczne zagrożenia współczesnej rodziny.

Następnie prof. zw. dr hab. Bożena Matyjas (UJK) wygłosiła referat zatytułowany: „Dzieciństwo w rodzinie rozwiedzionej. Formy wsparcia psychologiczno-pedagogicznego rodzin po rozwodzie". Na wstępie prelegentka scharakteryzowała rzeczywistość, w jakiej przychodzi żyć dziecku, które doświadczyło rozwodu rodziców. U dzieci może pojawić się agresja, bunt, depresja, a także trauma o dużym znaczeniu dla przyszłości. Dziecko może utracić możliwość zaspokajania podstawowych potrzeb, między innymi: potrzeby bezpieczeństwa, a także mieć tendencję do przejmowania odpowiedzialności za rodziców i rozpad ich związku.

$\mathrm{W}$ dalszej kolejności z referatem „Terapia jako forma pomocy rodzinie w powrocie do równowagi" głos zabrał dr hab. Andrzej Ładyżyński, prof. UWR. W swoim wystąpieniu wskazał na czynniki pozwalające walczyć z kryzysem w rodzinie: system wzajemnych przekonań, wzorce organizacyjne oraz wzorce komunikacji stosowanej w rodzinie. Prelegent postulował traktowanie rodziny jako pacjenta zbiorowego, ze skłonnością ku myśleniu cyrkularnemu, podkreślając, że zgodnie z tym myśleniem rodzina to więcej niż prosta suma jej członków. Odwołując się do systemowej teorii rodziny, wskazał na znaczenie zasobów rodzinnych, na bazie których można budować proces terapeutyczny.

Następnie ks. prof. zw. dr hab. Jan Śledzianowski wygłosił wykład zatytułowany „Rodzeństwo to więcej niż 500+”. Zaprezentował przeprowadzone badania nad młodzieżą w wieku 13-19 lat. Prelegent wskazał na następujące funkcje rodzeństwa: pobudzanie ambicji, wspieranie zainteresowań, troska o życie i bezpieczeństwo, spędzanie wspólnie wakacji i czasu wolnego, wspólne życie religijne oraz wpływanie na rozwój moralny rodzeństwa.

Na zakończenie tej części obrad wystąpił ks. prof. zw. dr hab. Marian Nowak z referatem „Pedagogika rodziny i wychowanie w rodzinie w świetle posynodalnej adhortacji apostolskiej Amoris Laetitia". Referujący wskazał na konieczność kształtowania sumienia w procesie wychowania. Wychowa- 
nie można opisać jako dojrzewanie w miłości. Wartość, do której wychowuje się, musi odznaczać się pięknem, które pociąga za sobą.

Po przerwie, w czasie której uczestnicy konferencji mieli możliwość oddania głosu na wybrany przez siebie plakat z sesji studenckiej, rozpoczęły się obrady w sekcjach. W pierwszej z ośmiu sekcji obrady odbywały się pod hasłem „Rodzina w kontekście historycznym i współczesnym”. Referaty zaprezentowało dziesięciu prelegentów, reprezentujących osiem ośrodków naukowych: dr hab. Barbara Kiereś (KUL): „Filozoficzna myśl Arystotelesa podstawą realistycznej teorii rodziny"; dr hab. Grzegorz Grzybek, prof. UR: „Metoda normatywno-konstrukcyjna w badaniu aspektów dotyczących rodziny”; dr Renata Doniec (UJ): „Kondycja wychowawcza rodziny w czasach socjalizmu realnego - konteksty życia i zasoby"; dr Edyta Zawadzka (APS): „Współczesne uzasadnienia celów wychowania rodzinnego - refleksja teoretyczno-empiryczna”; dr Ewa Rojewska (USZ): „Rodzina o personalistycznej orientacji wychowawczej jako istotne środowisko wychowania seksualnego młodzieży”; dr Magdalena Parzyszek (KUL): „Rodzina w zmieniającej się rzeczywistości społeczno-kulturowej”; mgr Dorota Zagrodnik (KUL): „Wychowanie w rodzinie współczesnej w świetle badań własnych”; mgr Magdalena Gajderowicz (KUL): „Pedagogika zza drutów. Elementy wychowania w grypsach więźniów obozu koncentracyjnego na Majdanku”; dr Anna Krasnodębska (UO): „Migracja a rodzina. Problemy rodzin migracyjnych".

W sekcji drugiej, zatytułowanej „Pedagogika rodzicielstwa”, głos zabrało osiem osób reprezentujących sześć ośrodków naukowych. Wystąpili następujący prelegenci: dr Martyna Kawińska (UKSW): „Rodzicielstwo w warunkach nowoczesności. Teoria i praktyka"; mgr inż. Ryszard Kusiak (Fundacja Dzieci i Ojców im. św. Jana Bosko): „Więzi rodzinne wobec alienacji rodzicielskiej”; mgr Bożena Miernik (KUL): „Więź emocjonalna rodziców z dzieckiem prenatalnym jako pierwszy etap wychowania w rodzinie”; dr Anna Śniegulska (UR): „Wychowawcza rola matki w spostrzeżeniach dorosłych córek”; mgr Marta Samorańska (KUL): „Przeciążenie zawodowe nauczycielek a konflikt ról”; mgr Karolina Ludwikowska (KUL): „Samotne rodzicielstwo w sytuacji zaginięcia współmałżonka”; dr Urszula Tokarska (WSNS): „Podnoszenie poziomu wiedzy pedagogicznej rodziców dotyczącej celów i zasad wychowawczych dziecka w rodzinie (w świetle badań)”; dr Anna Błasiak (Akademia Ignatianum): „Nowy wymiar rodzicielstwa - wybrane aspekty".

W obradach w sekcji trzeciej: „Rodzina przestrzenią rozwoju dzieci i młodzieży”, wystąpiło dziewięciu prelegentów z pięciu ośrodków na- 
ukowych. Swoje wystąpienia przedstawili: prof. zw. dr hab. Krystyna Chałas (KUL): „Rodzina przestrzenią radości i cierpienia młodzieży”; dr hab. Edward Nycz, prof. UO: „Młodzież a międzypokoleniowy przekaz statusów i wartości - refleksja badacza"; dr Anna Lendzion (Akademia Polonijna w Częstochowie): „Dziedzictwo kulturowe przekazywane pokoleniowo w rodzinie w poglądach i doświadczeniach studiującej młodzieży"; dr Aleksandra Pyrzyk-Kuta (US): „«Nie możesz pozwolić, abym upadł!»-cierpienie, sprzeciw i wołanie młodzieży o pomoc w twórczości literackiej. Aspekty diagnostyczne i terapeutyczne”; dr Marta Buk-Cegiełka (KUL): „Dziecko w wieku wczesnoszkolnym wobec wartości rodziny"; ks. dr Paweł Brudek (KUL): „Dziadkowie w akcji. Znaczenie dziadków w procesie wspierania rozwoju dziecka w prenatalnym okresie życia. Perspektywa teorii gerotranscendencji Larsa Tornstama”; dr Stanisława Włoch (UO): „Rodzina - znaczące środowisko wychowawcze w okresie dzieciństwa"; dr Sylwia Gwiazdowska-Stańczak (KUL): „Profil rodziny ucznia z wysokimi osiągnięciami szkolnymi”; mgr Justyna Sala-Suszyńska (UMCS): „Znaczenie rodziców w edukacji dziecka".

Hasłem przewodnim obrad w sekcji czwartej było: „Religijny wymiar wychowania w rodzinie". Swoje wystąpienia przedstawiło dziewięciu prelegentów z czterech ośrodków akademickich. Głos zabrali: dr hab. Alina Rynio, prof. KUL: „Znaczenie rodziny w chrześcijańskim wychowaniu dzieci i młodzieży w nauczaniu Kardynała Stefana Wyszyńskiego"; ks. dr hab. Stanisław Chrobak, prof. UKSW: „Przebaczenie i zaufanie w komunii rodzinnej. Uwagi na tle Amoris Laetitia"; ks. dr hab. Andrzej Łuczyński (KUL): „Wychowanie religijne $\mathrm{w}$ rodzinie w kontekście współczesnych przemian społeczno-kulturowych"; mgr Paulina Biegaj (UJ): „Nieposłuszeństwo dziecka wobec rodziców a papieski postulat miłości i czułości jako szansa na przezwyciężenie wychowawczego kryzysu"; mgr lic. Andrei Ahapau (KUL): „Specyfika wychowania w rodzinie muzułmańskiej w świetle wybranej literatury”; mgr Iryna Ahapava (KUL): „Czas wolny w myśli katolickiej w świetle wybranej literatury”; mgr Karolina Siwek (KUL): „Przygotowanie do małżeństwa i rodziny w świetle współczesnych transformacji. Na podstawie adhortacji papieża Franciszka Amoris Laetitia"; mgr Ewa Łaskarzewska: „Rodzina wielodzietna $\mathrm{w}$ mediach społecznościowych jako realizacja apeli papieży zawartych w Orędziach na Światowy Dzień Środków Społecznego Przekazu”; mgr Katarzyna Hryszan (KUL): „Dziecko z autyzmem w rodzinie. Kontekst wychowania religijnego".

W sekcji piątej zatytułowanej ,(Nie)zagrożone relacje interpersonalne w rodzinie" wystąpiło dziesięciu prelegentów z dziewięciu ośrodków aka- 
demickich: dr Ewa Dybowska (Akademia Ignatianum): „System rodzinny według Stephena R. Coveya. Inspiracje dla wychowania we współczesnej rodzinie”; dr Zbigniew Chodkowski (UR): „Czynniki wspomagające rozwój rodziny”; dr Sabina Zalewska (UKSW): „Samotność i osamotnienie w małżeństwie. Narracje biograficzne i doświadczenia małżonków"; prof. nadzw. dr hab. Józef Szopiński (Wyższa Szkoła Humanitas): „Zranienia w rodzinie. Kompleks Elektry”; dr hab. Agata Popławska, prof. NWSP: „Rodzina wobec zagrożeń cyberprzestrzeni”; dr Sylwester Bębas (UP): „Rodzina w sytuacji problemów i zagrożeń świata wirtualnego"; mgr Ewa Domarecka (UMCS): „Rodzina w sytuacji uzależnienia seniora od alkoholu - studium przypadku”; mgr Emilia Mulawa (KUL): „Samobójcza śmierć rodzica w narracjach dorosłych dzieci - perspektywa pedagogiczna”; mgr Łukasz Mrózek (UPJP2): „Samobójstwo refleksją rodzinną".

Sekcja szósta przeprowadzona została pod hasłem: „Rodzina wobec problemów". Wystąpiło dziesięciu prelegentów reprezentujących sześć ośrodków naukowych. Wygłoszono następujące referaty: mgr Ewa Nizio (KUL): „Niepłodność jako źródło stresu w małżeństwie i rodzinie oraz sposoby radzenia sobie z nim”; ks. mgr Jarosław Czapliński (KUL): „Adopcja - początek czy koniec trudności i problemów osób bezdzietnych?”; dr Agnieszka Bochniarz (UMCS): „Samoocena rodziców z niepełnosprawnością ruchową”; dr Ewa Dziewońska (Akademia Ignatianum): „Wybrane formy pracy terapeutycznej z rodziną z dzieckiem niepełnosprawnym. $Z$ doświadczeń zawodowych terapeuty rodzinnego"; mgr Katarzyna Sowa: „Niepełna sprawność dziecka - problem, a może powołanie”; dr Izabela Gątarek (UKSW): „Nauczanie domowe w kontekście choroby przewlekłej dziecka”; mgr Agnieszka Siedliska (SP ZOZ Puławy): „Aktywność wychowawcza środowiska rodzinnego w sytuacji choroby dziecka na przykładzie badań dzieci w szkole przyszpitalnej w Puławach"; mgr Magdalena Woźniak (KUL): „Praca z rodziną dziecka z autyzmem na przykładzie praktyki pedagogicznej”; dr Krzysztof Zajdel (UZ): „Problemy rodziny dotyczące aspektów związanych z eutanazją”; mgr Joanna Kata (UMCS): „Psychospołeczne przejawy kryzysu współczesnej rodziny".

W obradach w sekcji siódmej „Rodzina w problematyce resocjalizacyjnej” swoje wystąpiło osiem osób. Prelegenci reprezentowali pięć ośrodków naukowych. Głos zabrali: dr hab. Tadeusz Sakowicz, prof. UJK: „Potęga sakramentalnego wymiaru rodziny w dobie totalnego jej zagrożenia”; dr hab. Beata Maria Nowak (Pedagogium WSNS): „Rodzina pochodzenia w narracji recydywistów penitencjarnych"; mgr Małgorzata Grabowska (KUL): „Retrospektywna ocena postaw rodzicielskich przez kobiety niedostoso- 
wane społecznie”; mgr Angelika Sikorska (UŁ): „Dezorganizacja życia rodzinnego w sytuacji uwięzienia rodzica"; mgr Małgorzata Osińska (UMCS): „Znaczenie rodziny w pracy resocjalizacyjnej ze skazanym. Czynnik ryzyka czy zasób?”; mgr Gabriela Matczak (UŁ): „Znaczenie rodziny w pracy z wychowankiem młodzieżowego ośrodka wychowawczego o charakterze resocjalizacyjno-rewalidacyjnym”; mgr Aleksandra Majsterek (KUL): „(Nie) zagrożona młodzież - wpływ nowoczesnych urządzeń medialnych na życie adolescentów, funkcjonujących we współczesnej rodzinie w czasie przemian społecznokulturowych".

W ostatniej sekcji, zatytułowanej „Współpraca z rodziną i wsparcie rodziny”, wystąpiło siedem osób reprezentujących trzy ośrodki akademickie. Referaty przedstawili: ks. dr hab. Adama Maj, prof. KUL: „Partnerstwo aksjologiczne rodziny i szkoły”; dr Magdalena Urbańska (UR): „Opieka - płaszczyzna współpracy rodziny i szkoły podstawowej - na przykładzie badań przeprowadzonych na terenie powiatu tarnowskiego (Polska) oraz Egeru i Ózd (Węgry)”; dr Paulina Forma (UJK): „Rodzina z przemocą jako odbiorca działań pomocowych (w świetle badań własnych i doświadczeń Ośrodka Pomocy Społecznej)”; dr Katarzyna Braun (KUL): „Wolontariat jedną z form wsparcia rodziny dysfunkcjonalnej"; dr Karolina Mirosław (KUL): „Rodzina w trosce pracownika socjalnego”; mgr Małgorzata Szczeszek (KUL): „Wspieranie rodziny w opiece nad osobą starszą na przykładzie Dziennego Oddziału Psychogeriatrycznego w Lublinie"; mgr Michał Kotala (KUL): „Zastosowanie gier planszowych w profilaktyce i terapii uzależnień dzieci i młodzieży".

Po wystąpieniach w sekcjach uczestnicy konferencji spotkali się na obradach podsumowujących. Tę część spotkania poprowadziły dr hab. Barbara Kiereś oraz dr Magdalena Parzyszek. Przedstawiono w niej sprawozdania z sekcji tematycznych. Ogłoszono także wyniki konkursu na najlepszy plakat przygotowany przez studenta. Następnie mgr Emilia Mulawa, Prezes Fundacji Centrum Opieki nad Rodziną „COR”, wyraziła zadowolenie z kolejnej inicjatywy realizowanej we współpracy z Katedrą Pedagogiki Rodziny KUL. Na zakończenie głos zabrała dr hab. Danuta Opozda, kierownik Katedry Pedagogiki Rodziny. Podsumowując obrady konferencyjne, wyraziła zadowolenie i wdzięczność za przybycie i wspólne świętowanie 20-lecia funkcjonowania Katedry. Podkreśliła także znaczenie dokonanego namysłu pedagogicznego jako przyczynku do budowania systematycznej wiedzy o rodzinie na gruncie pedagogiki. 
